\title{
THE REPRESENTATION OF THE MONSTER AS THE CASTRATING MOTHER: THE PSYCHOANALYTICAL APPROACH TO MAMA
}

\author{
Tuna TETiK*
}

Received: 21.08.2020 - Accepted: 26.09.2020

Tetik, T. (2020). The representation of the monster as the castrating mother: The psychoanalytical approach to Mama. Etkileşim, 6, 82-95. doi: 10.32739/etkilesim.2020.6.76

This study complies with research and publication ethics.

\begin{abstract}
This article aims to reveal and discuss the representation of the monster figure as the castrating mother in the movie titled Mama (Andrés Muschietti, 2013). The study argues that the movie's specialty is based on the characterization of the monster with psychoanalytical connotations. The monster and the female figure are often portrayed as related characters in the horror genre. Conventionally, the binary opposition between the male and the female causes to represent the female with monstrous qualities in the genre. The castration complex provides male characters to define females featuring monstrous attributions. This study broadens the argument in the field by explicitly analyzing the maternal monster character called Mama in Mama (2013) with psychoanalytical studies by seminal works of the theoreticians in the field. For this purpose, the castrating complex, the uncanny concept, and ancestor examples of monstrous characters in the genre are researched to gain an understanding of the characterization of the monster called Mama within the psychoanalytical perspective. The threat of the Mama as a castrating figure, the maternal qualities as a substitute mother, and terrifying appearance as uncanny characteristics are analyzed through the movie's narrative structure. Besides the characterization of the Mama as the castrating mother, its relation to the setting of the movie is highlighted as an uncanny relationship, which is a conventional element in the horror genre. This study intends to contribute to the field with an interdisciplinary approach to analyze a horror movie within the psychoanalytical perspective. In this way, the representation of the monster related to the material qualities and the function of the monstrous character both in the narrative structure of the movie and the genre are discussed and revealed.
\end{abstract}

Keywords: monster, mother, castration, uncanny, horror.

*PhD/Expert, Bahçeşehir University, Faculty of Communication, tuna.tetik@comm.bau.edu.tr, Orcid: 0000-0002-5135-957X

\section{ETKileşim | Üsküdar Üniversitesi | iletişim Fakültesi |Akademik Dergisi}




\title{
KASTRE EDICI BIR ANNE OLAN CANAVARIN TEMSILI: MAMA'YA PSIKANALITIK YAKLAŞIM
}

\author{
Tuna TETiK*
}

Gönderim Tarihi: 21.08.2020 - Kabul Tarihi: 26.09.2020

Tetik, T. (2020). The representation of the monster as the castrating mother: The psychoanalytical approach to Mama. Etkileşim, 6, 82-95. doi: 10.32739/etkilesim.2020.6.76

Bu çalışma araştırma ve yayın etiğine uygun olarak gerçekleştirilmiştir.

\section{Özet}

Bu çalışma; Mama (Andrés Muschietti, 2013) filminde yer alan canavarın bireylerin iktidarını tehdit eden ve onları hadım eden bir figür olarak nasıl temsil edildiğini tartışmayı hedeflemektedir. Çalışma, Mama filmini özel ve özgün kılanın canavar temsilinin barındırdığı psikanalitik çağrışımlar olduğunu öne sürmektedir. Canavar ve kadın figürü korku türü içerisinde sıklıkla ilişkili karakterler olarak tanımlanmaktadır. Tür içerisinde geleneksel olarak, kadın karakter canavarımsı özellikleriyle erkek ve kadın arasında yaratılan ikili karşıtlıklar çerçevesinde konumlandırılmaktadır. Hadım edilme kompleksi erkek karakterlerin kadınları canavarımsı atıflarla tanımlamasına sebep olmaktadır. Bu çalışma, korku türü üzerine yapılan akademik çalışmalardaki bu görüşlere, Mama filmindeki Mama adlı anaç canavarı psikanaliz alanındaki önde gelen savlarla inceleyerek katkı sağlamayı hedeflemektedir. Bu amaç doğrultusunda; hadım edilme kompleksi, tekinsizlik konsepti ve tür sinemasındaki öncül canavar karakter örnekleri ile aynı adlı filmde yer alan Mama adlı canavarı psikanaliz disiplini içerisinde inceleyerek alan içindeki tartışmalara daha derin ve detaylı bir anlayış kazandırılması üzerine çalışılmıştır. Hadım edici bir tehdit olarak canavar Mama, canavarın anaç özellikleri ve ikonografik temsili filmin anlatısı kapsamında analiz edilmiştir. Bununla birlikte, filmde kullanılan ana mekanlar da psikanalitik alan içinde tanımlanan tekinsizlik konsepti bağlamında incelenerek korku türünün geleneksel konvansiyonlarından birisi olan tekinsiz mekanlara disiplinler arası bir bakış açısı geliştirilmiştir. Bu çalışma, tür sinemasını psikanalitik bir yaklaşımla inceleyerek alana katkı sağlamayı amaçlamaktadır. Bu yolla, filmdeki canavar temsilinin anaçlıkla olan ilişkisi ve canavar karakterin hem filmin anlatı yapısı içindeki hem de tür sinemasındaki fonksiyonu tartışılmıştır.

Anahtar Kelimeler: canavar, anne, kastrasyon, tekinsiz, korku.

* Doktor/Uzman, Bahçeşehir Üniversitesi, iletişim Fakültesi, tuna.tetik@comm.bau.edu.tr, Orcid: 0000-0002-5135-957X 


\section{Introduction}

This article investigates several representations of the mother figure in the horror genre. Specifically, the study focuses on the movie called Mama (Andrés Muschietti, 2013) in order to discuss and reveal the mother figure's characterization concerning the psychoanalytical approach. Psychoanalysis is a broad discipline that allows analyzing many texts in several fields. The horror genre is mostly examined in a psychoanalytical perspective to gain an understanding of the genre's attitude on characterization and representation of female figures. The woman could be represented with many different identities, such as a daughter, a sister, and a mother. This study argues that the mother figure in Mama (Muschietti, 2013) is portrayed as a monstrous and castrating character by the psychoanalytical connotations. For this purpose, the argument is oriented on Barbara Creed's (1993) seminal work titled Monstrous Feminine: Film, Feminism, Psychoanalysis.

Mama's (2013) original story is based on Muschietti's short film (2008). The director, Muschietti, made a short film called Mama in 2008. Muschietti told the story of two sisters in the nightmarish three minutes. Although Mama's running time (Muschietti, 2008) is not quite enough to tell a three-act structure-modeled story, Muschietti achieved to reveal the thrilling atmosphere of horror and the monster with material qualities. Five years after the short film was released, Muschietti had a chance to get his feature-length movie titled Mama (Muschietti, 2013). He brought a similar nightmarish atmosphere and the monster with the same qualities in a more extended narrative. To briefly emphasize, Mama (2013) is the story of two sisters, who have been possessed and adapted by an unknown entity called Mama. Two sisters are abandoned in a forest cabin - a cottage - where Mama is willing to feed and nurture them. When they are founded in the forest, two adult relatives take on their care in a suburban home. However, Mama follows them and terrorizes adults to become substitute mother of two sisters again.

Before analyzing the movie, several concepts in psychoanalysis related to the horror genre and different representations of the female characters in the genre are mentioned. This study aims to broaden an understanding and contribute to the field by approaching film studies with a psychoanalytical perspective. Therefore, many arguments in the essential works of Hélène Cixous, Laura Mulvey, and Julia Kristeva are researched to gain an expanded view on the movie's narrative structure and characterization of the antagonist.

The study examines the monstrous mother's characterization related to the concept called abjection with the arguments in Kristeva and Creed's works. Besides the characterization of the maternal monster in Mama (Muschietti, 2013), the setting is analyzed within the Freudian concept of the uncanny (1919). The horror genre creates tension by not only characteristics of the antagonists but also iconography of the places. In many examples, the antagonist and the setting are related to each other. Similar to Dracula in Tran-

\section{4 | ETKíleşim |Yıl3|Sayı 6| Ekim 2020}


sylvania, Norma Bates in Bates Motel, and Freddy Kruger on Elm Street, Mama and the setting are in a relation that creates the uncanny tension of the movie. The study reveals the unique characteristic of the monster figure as a castrating mother in Mama (Muschietti, 2013) within psychoanalytical connotations related to the featuring maternal qualities and monstrous sides. Therefore, several concepts in the field, the theoretical background, and the ancestor examples in the genre are mentioned to clarify the unique characterization of the monstrous figure in Mama (2013).

\section{An Overview of the Monstrous Feminine}

"Visual Pleasure and Narrative Cinema" by Laura Mulvey on the psychoanalytic theory could be accepted as a political weapon in the field. Mulvey states that "the representation of the female form in a symbolic order in which, it speaks castration and nothing else." (1989: 14). The castration complex is caused by male anxiety that comes from fear about the phallus could be castrated. However, in cinematic representations, especially in the horror genre, we can see castrating female figures, which are often referred as vagina dentata. This female is a mother. Nonetheless, a monstrous mother is represented with the capability of castration.

Although a great deal has been written about horror film, very little of that work has discussed the representation of woman-as-monster. Instead, emphasis has been on woman as victim of the (mainly male) monster. Why has woman-as-monster been neglected in feminist theory and in virtually all significant theoretical analyses of the popular horror film? (Creed, 1993: 1).

The question clearly states that the role of feminine in contrast to masculine have been suppressed in the medium of cinema as well as in the other art forms. When we encounter with a criticism on a horror film, it is not mainly related to the monstrous feminine. However, the analysis is usually based on the woman in a victim role. Through this victimization, these types of analysis also support the pleasure in looking to female body. Mulvey (1989) argues that movies offer many different kinds of pleasures. One is scopophilia, the pleasure in looking. Thus, there is a pleasure in being looked at. Mulvey adds that "at the extreme, it can become fixated into a perversion, producing obsessive voyeurs and Peeping Toms whose only sexual satisfaction can come from watching, in an active controlling sense, an objectified other." (Mulvey, 1989: 17). Therefore, the pleasure of looking could lead an obsessive act where the person could not get pleasure without the act of voyeurism. In cinema, the voyeuristic approach towards female body is related to the notion of possession of woman.

Being possessed is not desirable for a masculine Imaginary, which would interpret it as passivity - a dangerous feminine position. It is true that a certain receptivity is "feminine". One can, of course, as History has always done, exploit feminine reception through alienation (Helene Cixous, 1996: 86). 
What Cixous points out in this phrase argues that, the feminine position is mostly described through the passivity. On the contrary, the masculine position particularly signifies the activity. To relate this notion to binary oppositions which was originated from Saussurean structuralist theory, Greg Smith argues that "a pair of related terms or concepts that are opposite in meaning. Binary opposition is the system by which, in language and thought, two theoretical opposites are strictly defined and set off against one another" (1996: 384). Hence, this concept of binary opposition between the feminine and the masculine is connecting to the horror film. Creed emphasizes on the concept of opposition through the portrayal of male and female characters in the horror film. She argues that "the male monster 'disturbs identity, system, order'. It does not respect borders, positions, rules" (Creed, 1993: xviii). The representation of monstrous feminine and masculine in horror film is a collided and bound to one another and raises question of gender representation all together.

At first, I would like to emphasize on the monstrous feminine in horror film with the support of Creed's arguments in her book titled "Monstrous Feminine". She quotes from Julia Kristeva in many arguments of her and presents a critical aspect in horror film, which had been neglected by several critics. She relates female monstrosity to the concept of Kristeva's abjection. Creed itemizes the approach on abjection in horror film into three categories: "first, the horror film abounds in images of abjection, foremost of which is the corpse, whole and mutilated, followed by an array of bodily wastes such as blood, vomit, saliva, sweat, tears and putrefying flesh" (1993: 10). This definition of abjection is merely literal where the origin of abject is based on 'corpse'. As Kristeva mentions that, "the corpse, seen without God and outside of science, is the utmost of abjection. It is death infecting life. Abject" (ibid.). In the relation where women are represented as abject, there are several horror films that Creed focused on. The film called The Exorcist (William Friedkin, 1973) reveals one of the most significant examples of female body as abject. The character, Reagan, is a possessed thirteen-year-old girl. She is in the threshold between puberty to womanhood.

She becomes the castrating girl/woman, a figure designed to strike terror into the hearts of men. She also becomes a figure of extreme abjection as her body is transformed into a playground for bodily wastes. Her skin erupts in oozing sores, her hair hangs in a tangled filthy mat, she urinates on the carpet, spews green bile, and bleeds from her genitals. She masturbates with a crucifix and refers to herself as her mother's 'cunting daughter' (Creed, 1993: 40).

Reagan is a representation of abject through her body. Creed points out that the second way of representing abjection is where the monstrous figure crosses the borders (1993: 11).

Although the specific nature of the border changes from film to film, the function of the monstrous remains the same - to bring about an encounter between the symbolic order and that which threatens its stability. In some horror films the 
monstrous is produced at the border between human and inhuman, man and beast (Dr. Jekyll and Mr. Hyde, Creature from the Black Lagoon, King Kong); in others the border is between the normal and the supernatural, good and evil (Carrie, The Exorcist, The Omen, Rosemary's Baby...

This interpretation of abjection is based mainly on the oppositions where the abject emerges in the disturbance of the borders. As Creed gives examples on such monsters, the monstrous figure occurs in the margin. To address Derrida (1984) on his writings, the concept of margin is the state where you are in between of two things. Hence with the support of Derrida's implication on binary oppositions, the monstrous figure is abject because it occurs in between of two states, as; human and inhuman, normal and the supernatural. In this case, Psycho (Alfred Hitchcock, 1960) is a significant example where the "monstrous is produces at the border which separates those who take up their proper gender roles from those who do not" (Creed, 1993: 149). Norman Bates disguises as her mother. Then, he castrates woman who interacts with him in Psycho (1960). As Creed argues that "Mrs. Bates is dead but lives in Norman's mind as his alter ego... In Norman's case she is so powerful that he gives up his own identity" (1993: 150). Thus, Creed claims that "the third way in which the horror film illustrates the work of abjection is in the construction of the maternal figure as abject" (ibid.). Creed underlines Kristeva's statement that "all individuals experience abjection at the time of their earliest attempts to break away from the mother" (ibid.). This abjection is the far most the closest definition that we can relate femininity to monstrous. The described abject is the mother's desire to keep the child with herself and not release it. Thus, as Creed mentions, "Kristeva argues that the maternal body becomes a site of conflicting desires" (1993: 11). To emphasize another prominent example from horror genre, the Brood (David Cronenberg, 1979), reveals the portrayal of woman as abject through the womb. According to Creed, "the womb represents the utmost in abjection for it contains a new life form which will pass from inside to outside...The horror film exploits the abject nature of the womb by depicting the human, female and male giving birth to the monstrous" (1993: 49).

The masculine representation in horror film is through the uncanny. In "Phallic Panic" Creed defines monstrosity of male that "in many instances akin to a folkloric and mythical shape-shifter who, as he transforms from one state to another, uncovers secrets about men that 'ought to have remained... hidden' specifically his desire to become 'other'" (2005: xv). The 'other' that Creed implies here is rely on the masculinity in the symbolic order. According to Creed, "since the classic male monster, in order to challenge the phallocentric symbolic from within, is aligned with the realm of the feminine, the animal and death" (2005: xv). This is the desire of becoming other, "to take up his place in the symbolic order, man has repressed desires that would otherwise mark him as female, other or animal" (2005: xvii). To focus on the masculinity of the monstrous in the horror film, Dracula (Terence Fisher, 1958) portrays 
a well-established example. Creed argues that "Dracula leads us to question the nature of phallic sexuality" where he also portrays an elegant monster, that we can find feminine features. On the other hand, in the film titled $A$ Nightmare on Elm Street (Wes Craven, 1984), the monstrous character, Freddy Krueger, is yet again a question of uncanny.

Freddy's trademark signs are hideously scarred face, his infamous gloved hands, with sharp butter knives attached (to slice his victims) and his striped jumper and fedora...Freddy is also associated with two qualities attached to the primal uncanny: woman and death...through his identity as a maternal male, a feminized spectral figure and a harbinger of death (Creed, 1993: 164).

Thus, the representation of male monstrous in horror film relies on the notions of female, animal, and death. This representation mainly questions the male rebellion against borders, positions, rules, and the symbolic order. These types of representations and prototypical examples constitute a base to examine a contemporary horror movie within the psychoanalytical perspective.

\section{The Representation of Monster Figure as an Uncanny and Castrating Mother in Mama (2013)}

The horror film, Mama (Andrés Muschietti, 2013), depicts the monstrous-feminine called Mama as castrating mother. The movie begins with the scene where the setting is placed outside of a house. There is a car with an open door in front of the house and we hear a gunshot. This scene continues with a father called Jeffrey (Nikolaj Coster-Waldau) getting his two little daughters: Victoria (Megan Charpentier) and Lilly (Isabelle Nélisse) into the car and they end up crashing over a cliff. They survive the crash and the path that lead them to a cottage in the woods.

Crucially, the constructions of the cottage and the home are quite particular settings. In most of the horror films, especially the ones which are related to ghosts or spirits, the 'house', in other words; the place, is a crucial aspect in the narrative. Dylan Trigg defines place within two separate point of views (2012: 3). On the one hand, the place could be seen as a setting, which is independent from the human life. Differently, the place is a thought of a product of human experience. The second definition could lose its importance without the human involvement. Thus, Trigg describes the experience and affectivity as one of the crucial parts of place (p.6). Bruce W. Kavin (2012) underlines the vitality of the place in the horror genre. According to him, the horror film is defined by its conventional elements, such as undead figures, monsters, bloody violence, and its attitudes toward those elements (2012: 4). Eventually, the horror film is produced for achieving the specific goal: to frighten and revolt the audience (ibid.). Similar to Kavin's definition, in her seminal essay called "Film Bodies: Gender, Genre, and Excess" Linda Williams (1991) describes horror genre as one of the body genres of cinema. According to Williams, melodrama, horror, and pornography are female body genres in which victimization of 
female characters provide the audiences different kinds of pleasure (1991: 6). Mama (Muschietti, 2013) positions many female characters in different kinds of roles. Two little sisters and Annabel (Jessica Chastain) are surrounded by a maternal entity in a creepy house. Therefore, the place in Mama (2013) could be seen as the house of terror with many uncanny hallmarks. Creed (2005: 4) clarifies the relation of Freud's (1919) the uncanny definition to the place.

Freud was particularly interested in the relationship of the uncanny to the 'home'an important connection for his study, as so much horror originates in the home. Heimlich is used to refer to places such as the home, a friendly room, a pleasant country scene, a person who is friendly, or a family. It can also refer to a secret place or action, an act of betrayal (behind someone's back), to someone unscrupulous.

To mention Freud's ideas on the uncanny, several definitions of the uncanny in his work should be clarified. Freud (1919: 74) describes the uncanny as "the class of the terrifying which leads back to something long known to us, once very familiar." Moreover, the uncanny could proceed from "something familiar which has been repressed" (ibid.). 'Unintentional returns' and 'involuntary repetitions' constitute core ideas of Freud's on the concept of the uncanny (Trigg, 2012: 35). The uncanny, unheimlich, is the opposite of heimlich. Heimisch, as a German adjective, means 'familiar,' 'native,' and 'belonging to the home' (Freud, 1919: 75). Freud prefers to describe the uncanny by the combination of familiar but strange things such as doubles, childhood homes, peoples related to death or dead bodies (1919: 85-100). Trigg states that "the uncanny is strange rather than shocking, weird rather than annihilating" (2012: 28). Therefore, the concept of uncanny has been the field of horror cinema. Robert Spadoni (2007) investigates uncanny bodies in the early horror genre and their effects on the contemporary examples. His research area is mainly based on the early sound films and their relation to the origin of the horror film. Spadoni describes the uncanny bodies between unrealism and the body, which are far from the mind and realism (2007: 11). Another important study on this filed, "the Unconcept" (Anneleen Masschelein 2011) explores the uncanny from the Freud comprehensive essay (1919) to $21^{\text {st }}$ century's artworks. Masschelein states that the uncanny's recurring element in the visual art is the vitality of the human figure (2011: 148). Many examples related to uncanny could be in different forms such as dolls, giants, body parts, corpses, the human, even the posthuman (ibid.). Thus, the concept of uncanny could be associated with many things from places to living or dead beings.

From this perspective, the home and the cottage are displayed as Heimlich in Mama (Muschietti, 2013). To clarify my opinion on this claim I would like to analyze the representations of both the home and the cottage. To start with the cottage, our first encounter with this place is the scene after the father crashes the car. He finds a cottage which is named 'Helvetia' in the woods and enters there with his two daughters. The cottage is dark, dreadful, and messy. Inside the cottage, there are slight implications that this place is used to be a 
home. However, the darkness covers the whole area and it is clear that, this is not a safe place. Thus, the cottage in Mama (2013) is the representation of a Heimlich setting where we use the term as a place of secrets and darkness. Creed mentions that "in terms of Schelling's and Freud's definitions, uncanniness is produced through the act of revelation, of bringing something horrific into view" (2005: 28). Importantly, our first encounter with Mama, the maternal monster, is in the very early scenes in the movie. When the father decides to commit suicide, he takes off her older daughter's glasses. When he points the gun towards himself, a figure appears and attacks to him. But the interesting aspect here is that, we, as audience, are watching this attack of unknown figure through the daughter's eyes. That's why her eyes cannot see much without her glasses, we, as audience, cannot see much about what is going on in that scene. According to Creed, "the uncanny in the film is produced most often as an effect of looking, specifically in relation to the uncanny gaze" (2005: 30). What we see in the scene is a black shaped floating figure is attacking and killing the father. We are looking at the shape, not turning our heads away from the screen. The figure as the representation of uncanny gaze allows us to observe what the little girl can see without her glasses, even though we want to confront the uncanny.

The continuity of uncanny depiction is visualized with the home. After Mama's attack on the father, the scene continues with the Lucas (Nikolaj Coster-Waldau) and Annabel's house. Lucas is the twin brother of the father of little girls, Jeffrey. We see a quick section of their life where we learn that Lucas is a painter and Annabel is in a rock band. In this sequence of the movie, Lucas hires a searching team for his brother and his two nephews. Then, he gets a phone call when the little girls are founded in a cottage. The girls have been living in this place for a time, they have adapted to wild life. However, they show dangerous vital activities. A psychiatrist takes care of them for a while and uses some therapy techniques to figure out how did they manage to survive for a long time by themselves. In this moment we learn about the figure, Mama, for the very first time. The facility of the psychiatrist offers Lucas and Annabel a home to raise the girls in there. At this point Creed's definition on uncanny should be highlighted (2005: 5):

The double meaning of Heimlich is important to a discussion of the uncanny as it underlines the close association between these two concepts: homely/unhomely; clear/obscure; knowable/unknowable...This double semantic meaning is important for a discussion of the workings of the uncanny in the film as the latter is often produced at the border... when for instance the friendly inviting place of refuge suddenly becomes hostile and uninviting.

The home, where Annabel and Lucas start to live with Victoria and Lilly, appears as a safe and homely environment. However, the connection of the girls to Mama through the cottage, infects this home. Then, the house starts to become an uncanny place. I would like to refer to Teresa Fenichel's work titled "Uncanny Belonging: Schelling, Freud and the Vertigo of Freedom".

90 | ETKileşim | Yıl3|Sayı 6| Ekim 2020 
Importantly for Freud, the word "unheimlich is itself ambiguous, suggesting both intimate knowledge and uncomfortable mystery-at-home-ness and not at-homeness...The word, divided in itself, simultaneously signals the ambiguity of alienation and absorption: it enacts the "unhomely home" that marks the dual anxieties of life (Fenichel, 2015: 15).

While the cottage represents us the pure darkness and dreadfulness, the home, where they live in, is starting to turn from intimate place to uncomfortable mystery. Mama is attached to the girls as a maternal figure and through their strong connection, she projects her uncanniness to the home. The name 'Mama' that the girls give to this monstrous figure is actually the uttermost clarification of the uncanny. For Victoria and Lilly, Mama is a substitution of their parents. Significantly, they develop a relationship with the figure so deeply. However, this figure is dark unlike a mother, she represents a terrifying presence. Hence, while Mama is a maternal to the girls, she is also a monstrous feminine. Creed argues that "the uncanny gaze is not always abject. Because as Kristeva argues, there is nothing familiar about the abject, the abject gaze always occurs when the spectator looks away" (2005: 32). Yet in this film's case, I conceive this statement as an opposition. It is true that the uncanny gaze is not always abject. But as Creed cites from Hélène Cixous that "the uncanny gaze uncovers what should have remained hidden - it creates a gap" (2005: 33). In this gap, through this film, we encounter a figure which is uncanny but also abject. Although Kristeva discusses that there is nothing familiar with abject, the figure, Mama, is a nurturing maternal presence where she becomes an uncanny through her vague shape. Mama is suspicious shadowy figure in the first few scenes in the film. When she comes out in to the light, we confront with this monstrous feminine as a castrating mother. I claim that the gap Cixous mentioned could be associated with the definition of this maternal monster figure. In my opinion Mama shows both abject and uncanny qualities in her nature.

First of all, I would like to state the abject nature of Mama. The Mama is a clear depiction of an undead corpse. Kawin describes the undeads as "[figures] have died and come back, not to life but to a state hard to identify as living or dead, usually in their own bodies" (2012: 110). However, Kawin uses the definition to describe vampires, zombies, and mummies. However, monsters could often have ghostly qualities, which are immaterial and disembodied in many times. The destructiveness and the repulsiveness of a monster could be a matter of monster's physical form. Therefore, we fear the monster due to its awful appearance and its power (ibid.). Even though Mama has material qualities, it's appearance and power cause the fear and tension. When we see Mama in the home, she was a shadowy figure. After she comes out of the darkness and shows us the actual shape, she is a ghostly spiritual being which originates from a corpse. The moth metaphor is somehow a sign that we can relate her being to a corpse. Moths appear when her presence is in the scene. 
Thus, this sequence reminds us that she is not only uncanny but also an abject. In her abject nature, her maternal figure correlates with monstrous feminine as castrating mother. I would like to support my argument using Psycho as a reference to this notion. The relationship of Mama with Victoria and Lilly is almost similar to the relationship between Norman and Norma Bates as it was depicted in the film, Psycho. In Psycho, the castrating mother is extremely protective for her son. She is threatened from any woman who is interacted with Norman. In Mama (Muschietti, 2013), the monstrous figure's back story validates that she is an overprotective mother, even she was willing to commit suicide in order to keep her child. When she transforms into a spiritual being, she attaches herself to Victoria and Lilly maternally. While she nurtures two little girls in the cottage, she associates her loss with the girls when they have been found by search team. Because she is unwilling to give away the girls, she becomes threatened from anyone who is near the girls. The first aggression of Mama is towards Lucas. In my view, she is motivated to castrate / eliminate men, in the symbolic order. She eliminates the father figures literally (killing Jeffrey) and symbolically (expelling Lucas from home). Her jealousy is reflected on the other characters who interfere to the relationship of her with the girls. Mama's castrating appearance is symbolized through her phallic shaped fingers and floating hair. She uses her phallic fingers to murder any threat that comes across to the connection of her to Victoria and Lilly. Thus, Mama's being presents us an abject figure which portrays as a castrating mother. More crucially, Mama is uncanny due to her nature.

\section{Conclusion}

To evaluate and summarize Creed's argument, this could be claimed that she criticizes that female body is defined according to male body by patriarchal view from past to the present. Female body is represented and seen as a deformed version of male body in the horror genre. A woman character's body is seen as marked, impure, and a part of the natural/animal world. Whereas the male body signifies integrity, cleanliness, and solidity, the female body possesses none of these characteristics. Margaret Miles argues that "the most concentrated sense of the grotesque comes from the image of women because of their associations with natural events such as sex and birth which were seen as 'quintessentially grotesque'" (1989: 147). In The Brood (1979), the female character gives birth without the agency of male. But the infants are born as deformed creatures. The movie implies that a woman can only bring a deformed child into the world without a man. Child birth and menstruation are seen as two events in the woman's life that have own side of abject. Woman regenerates herself by menstruation and generates her offspring by child birth. Woman's womb is also seen as a site of terror because it bleeds. Blood flows from the inside to the outside of woman's body are viewed as an abject quality. The womb is associated with the concept of vagina dentata

\section{2 | ETKiLeşim |Yıl3|Sayı 6| Ekim 2020}


which could be described as castrating female genitals. Vagina dentata represents the mouth of hell and a trap. But there is an important point, female with vagina dentata is a castrator figure, not a castrated one. Moreover, woman is related to the death. That's why she is related to the life. Her fertility signifies reproduction and life. These views are statements, which Creed strives to criticize. According to Creed, woman is not a passive figure. However, the representations of female figures make woman characters passive. Creed struggles to highlight that the wrong image of woman is about man's perspective which is based on patriarchal view and symbolic order. She mentions that man always struggles to constitute hegemony on woman because of his fear of losing power, castration complex, fragility of masculinity, and possibility of the symbolic order's downfall.

In Mama (Andrés Muschietti, 2013), the monstrous mother, Mama, is a distorted figure which has maternal qualities and uncanny features. Mama comes from the death in order to save and possess two little sisters. Mama is an uncanny figure with her dark silhouette and ghostly appearance. Mama hides in the dark between the curtains. Mama has to stay there but she comes out and attacks Luke and Annabel. Although Mama has to remain hidden in the dark, she comes out to light, that makes an uncanny sense. The confusion of the borderline between death and life, dark and light not only provides an uncanny feeling but also has abject qualities. The ambiguity of the distinction between death and life has an abject side. Mama creates her habitat with large moths and web-like patterns on the walls and inside the closets. These webs and moths have also abject qualities. Victoria and Lilly play with a doll which is made by branches and woods. Thus, we could define the doll as a toy has an abjection. Mama could be related to woman, animal, and death. Mama comes from death and has a characteristic between dead and alive due to her ghostly presence. The maternal monster, Mama, transforms into animals such as lots of dark butterflies and feeds two sisters with them. Therefore, Mama could be defined as a ghostly maternal monster, which is associated with primal uncanny in terms of woman, animal and death. Mama has connections to abjection in many ways such as wildness, ambiguity between death and life, and her habitat with large moths and web-like patterns. David Graven states that "the horror film inherits the woman's film's anxieties over and conflictual wishes for return to the mother, anxieties and wishes inextricably bound up with the regimes of patriarchal defenses against such a return to origins" (2011: 13). Besides Mama's appearance, her monstrous characteristic is related to the threat to patriarchy. Although Mama is a ghostly monster, she takes care of two little girls. Moreover, she protects, feeds, and raises them. Thus, the movie represents the mother figure as a castrating and uncanny monster within significant psychoanalytical connotations, which make the antagonist called Mama in Mama (Andrés Muschietti, 2013) more dimensional and unique character in the horror genre. 


\section{References}

Arnold J. (Director). (1954). Creature from the Black Lagoon. [Motion Picture]. United States: Universal Pictures.

Cixous, H. (1996). La jeune née. London: I.B. Tauris \& Co Ltd.

Cooper C. M. and Schoedsack, B. E. (Directors). (1933). King Kong. [Motion Picture]. United States: Radio Pictures.

Craven W. (Director). (1984). A nightmare on Elm Street. [Motion Picture]. United States: New Line Cinema.

Creed, B. (1993). Monstrous feminine: Film, feminism, psychoanalysis. Oxon: Routledge.

(2005). Phallic panic. Australia: Melbourne University Publishing Ltd.

Cronenberg D. (Director). (1979). The brood. [Motion Picture]. Canada: Telefilm.

Derrida, J. (1984). Margins of philosophy. The University of Chicago Press: Chicago, Illinois.

Donner R. (Director). (1976). The omen. [Motion Picture]. United States: Mace Neufeld Productions.

Fenichel, T. (2015). Uncanny belonging: Schelling, Freud and the vertigo of freedom (PhD Dissertation). Boston College University. BCU Libraries.

Fisher T. (Director). (1958). Dracula. [Motion Picture]. United Kingdom: Hammer Film Productions.

Freud, S. (1919). The "uncanny." Fantastic Literature: A Critical Reader, 74-101.

Friedkin W. (Director). (1973). The exorcist. [Motion Picture]. United States: Hoya Productions.

Greven, D. (2011). Representations of femininity in American genre cinema: The woman's film, film noir, and modern horror. Palgrave Macmillan: New York.

Hitchcock A. (Director). (1960). Psycho. [Motion Picture]. United States: Shamley Productions.

Kawin, F. B. (2012). Horror and the horror film. Anthem Press: London, New York, Delhi.

Kristeva, J. (1980). Powers of horror. New York: Colombia University Press.

Mamoulian R. (Director). (1931). Dr. Jekyll and Mr. Hyde. [Motion Picture]. United States: Paramount Pictures.

Masschelein, A. (2011). The unconcept: The Freudian uncanny in late-twentieth-century theory. State University of New York Press: Albany.

Miles, M. R. (1989). Carnal knowing: Female nakedness and religious meaning in the Christian west. Boston: Beacon Press.

Mulvey, L. (1989). Visual pleasure and narrative cinema. In visual and other pleasures, Language, Discourse, Society. Palgrave Macmillan, London.

Muschietti A. (Director). (2008). Mama. [Short Film].

94 | ETKileşim |Yıl3|Sayı 6| Ekim 2020 
(Director). (2013). Mama. [Motion Picture]. Canada: Toma 78.

Palma D. P. (Director). (1976). Carrie. [Motion Picture]. United States: Red Bank Films.

Polanski R. (Director). (1968). Rosemary's Baby. [Motion Picture]. United States: William Castle Enterprises.

Smith, G. (1996). Binary opposition and sexual power in 'Paradise Lost.'. The Midwest Quarterly, 37(4), 27-383.

Spadoni, R. (2007). Uncanny bodies: The coming of sound film and the origins of the horror genre. University of California Press: Berkeley, Los Angeles, London.

Trigg, D. (2012). The Memory of place: A phenomenology of the uncanny. Ohio University Press: Athens, Ohio.

Williams, L. (1991). Film bodies: Gender, genre, and excess. Film Quarterly, 44(4), 2-13.

Conflict of interest : There are no conflicts of interest to declare.

Financial support : No funding was received for this study.

Çıkar çatışması : Çıkar çatışması bulunmamaktadır.

Finansal destek : Finansal destek bulunmamaktadır. 